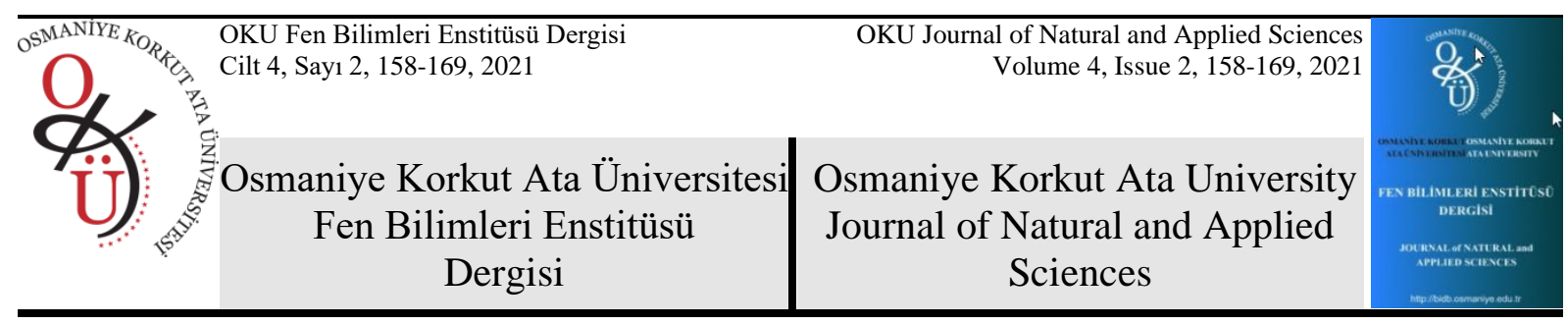

\title{
Hanehalkları Kırmızı Et Tüketim Alışkanlıkları Üzerine bir Araştırma: Doğrusal Olmayan Kanonik Korelasyon Uygulaması
}

\author{
Şenol ÇELIIK ${ }^{1 *}$ \\ ${ }^{1}$ Bingöl Üniversitesi Ziraat Fakültesi Zootekni Bölümü Biyometri ve Genetik Anabilim Dalı, Bingöl \\ ${ }^{1}$ https://orcid.org/0000-0001-5894-8986 \\ *Sorumlu yazar: senolcelik@bingol.edu.tr
}

\begin{tabular}{|c|c|}
\hline Araştırma Makalesi & ÖZET \\
\hline $\begin{array}{l}\text { Makale Tarihçesi: } \\
\text { Geliş tarihi: } 4 \text { Ocak } 2021 \\
\text { Kabul tarihi:22 Şubat } 2021 \\
\text { Online Yayınlanma: } 1 \text { Haziran } 2021\end{array}$ & $\begin{array}{l}\text { Çalışmada Bingöl ve çevre illerde yaşayan hane halkına kırmızı et tüketimi } \\
\text { alışkanlıklarını kapsayan bir anket uygulanmıştır. Bu amaçla, bireylerin, } \\
\text { seçilen demografik ve sosyoekonomik kavramlar bakımından kırmızı et } \\
\text { tüketim tercih ve alıskanlıklarının farklılık gösterip göstermedikleri }\end{array}$ \\
\hline 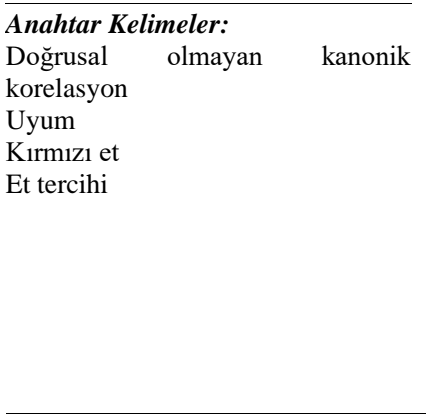 & $\begin{array}{l}\text { Analizi hakkında genel bilgiler verilmiştir. Daha sonra, verilerin istatistiksel } \\
\text { analizi yapılmıştır. Doğrusal Olmayan Kanonik Korelasyon Analizi } \\
\text { sonuçlarına göre, uyum değeri } 1,468 \text { olarak bulunmuştur. Analizde "aylık } \\
\text { gelir", "tüketim miktarı", "yaş" ve "alındığ1 yer" değişkenleri daha önemli } \\
\text { bulunmuştur. } 50 \text { yaş üstü aylık geliri } 2000-3000 \text { lira arası ve aylık gıda } \\
\text { harcaması } 2000 \text { lira üstü olan memurlar, kasaptan et alarak sakatat şeklinde } \\
\text { kırmızı et tüketmektedir. Aylık geliri } 3000-4000 \text { lira olan işçiler, serbest } \\
\text { meslek sahipleri ve kadınlar sığır etini marketten almaktadır. Aylık geliri } \\
\text { 4000-5000 lira ve } 5000 \text { lira üstü olanlar süpermarket ve hipermarketten et } \\
\text { almaktadır. }\end{array}$ \\
\hline
\end{tabular}

\section{A Study on Red Meat Consumption Habits of Households: Application of Non-linear Canonical Correlation}

\section{Research Article}

\section{Article History:}

Received: 4 January 2021

Accepted: 22 February 2021

Published online: 1 June 2021

\section{Keywords:}

Nonlinear canonical correlation Fit

Red meat

Meat preference

\begin{abstract}
In the present study, a questionnaire of red meat consumption habits has been applied to households living in Bingol and nearby provinces. For this purpose, it has been evaluated whether the preferences and habits of red meat consumption differ in terms of demographic and socio-cultural factors. First of all, general information on Nonlinear Canonical Correlation Analysis has been presented. Then, statistical data analysis has been carried out According to the Nonlinear Canonical Correlation Analysis results, the fit value was found 1,468. In the analysis, "monthly income", "consumption amount", "age" and "place of purchase" variables were found to be more significant. Civil servants over the age of 50 with a monthly income between 2000-3000 TL and with a monthly food expenditure over $2000 \mathrm{TL}$, purchase meat from the butcher and mostly prefer to purchase offal meat. Workers, self-employed persons and women with a monthly income of 3000-4000 TL purchase beef from the grocery. Those with a monthly income of 4000-5000 TL and over $5000 \mathrm{TL}$ purchase red meat from supermarkets and hypermarkets.
\end{abstract}

To Cite: Çelik Ş. Hanehalkları Kırmızı Et Tüketim Alıșkanlıkları Üzerine Bir Araştırma: Doğrusal Olmayan Kanonik Korelasyon Uygulaması. Osmaniye Korkut Ata Üniversitesi Fen Bilimleri Enstitüsü Dergisi 2021; 4(2): 158-169. 


\section{Giriş}

Kırmız1 et; gerek insan beslenmesinde gerekse coğrafi özelliklerinin büyükbaş ve küçükbaş hayvancılığa elverişli olması ve kültürel yapıs1 itibariyle Türkiye için ayrı bir önem taşır [1].

İnsanların sağlıklı ve dengeli beslenmelerinde hayvansal kaynaklı gıda grubunun bir çeşidi olan etlerin çok önemli yeri vardır. Protein, yağ, mineral madde ve vitamin içeriği açısından diğer gıdalara göre daha üstün bir gıdadır [2]. Sağglıklı ve dengeli beslenme için alınması gereken günlük protein ihtiyacının \%40-50"si hayvansal kaynaklı proteinlerden karşılanmalıdır [3].

Ülkelerin yaşam kalitesi standartlarının belirlenmesinde de et veya hayvansal proteinlerin tüketim düzeyi önemli kriterlerden biridir [4]. Örneğin 2018 y1lı verilerine göre, yıllık kişi başına kırmızı et tüketimi ABD'de $26,1 \mathrm{~kg}$, İsrail'de 20,5 kg, Kazakistan'da 19,3 $\mathrm{kg}$, Kanada'da $18 \mathrm{~kg}$, Şili'de $18,7 \mathrm{~kg}$, OECD'de 14,5, Paraguay'da 13,7 kg, İsviçre'de 13,3 kg, Yeni Zelanda'da 11,9 kg, Birleşik Krallık'ta 11,7 kg, Avrupa Birliği (27 ülke)'nde 10,8 $\mathrm{kg}$, Kolombiya'da 10,8 kg, Rusya'da 10,4 kg, Vietnam'da 9,3 kg, Meksika'da 8,9 kg, Türkiye'de $8,5 \mathrm{~kg}$, Misır'da 7,9 kg, Japonya'da 7,4 kg ve dünyada $6,4 \mathrm{~kg}$ olarak bildirilmiştir [5]. Türkiye'de kişi başına et tüketimi dünya ortalamasının üzerinde olsa da birçok ülkeden daha düşük düzeydedir.

FAO (Uluslararası Gıda ve Tarım Örgütü) 2019 yılı istatistiklerine göre Türkiye 1537 079 ton kırmızı et üretimi ile dünyada 10 . sırada yer almaktadır. Dünyada en fazla kırmızı et üreten ülkeler sirasıyla ABD (13 008 516 ton), Çin (11 428152 ton) ve Brezilya (10 333456 ton)'dir [6].

Türkiye'de, bireylerin gelir seviyesi, etin fiyatı ve tüketici tercihleri gibi etkenler et talebini ve tüketimini etkileyen etkenlerdir. Ayrıca tüketici alışkanlıklarında, bölgenin sosyoekonomik yapısının etkili olduğu söylenebilir. Et tüketimini arttırmaya yönelik çabaların yanında, tüketicilerin et tüketim alışkanlıklarının da belirlenmesi son derece önemlidir. Türkiye'nin nüfusu hızlı bir şekilde artarken, beslenme için kullanılan kaynaklarında artırılması, verimli hale getirilmesi ve değerlendirilmesi gerekir [7].
Türkiye'de kırmızı et tüketimini ekonomik nedenlerin dışında y1llık nüfus artışı oranı, ürünlerin kalitesi, dağılımı, tüketicinin eğitimi, etin hijyenik özellikleri, dini inançlar, sağlık sorunları, iklim, gelenekler, gıda ile ilgili reklamlar gibi çok sayıda faktör etkileyebilmektedir [8].

Türkiye'de et tüketim alışkanlığ 1 ile ilgili farklı illerde çalışmalar yapılmış ve kırmızı et tüketim eğilimleri tespit edilmiştir [9-12]. Kırmızı et konusunda yapılmış başka araştırmalara de rastlanmaktadır. Saygın ve Demirbaş [13], kırmızı et işleme sanayiine, hayvancılık sektörüne ve diş ticarette meydana gelen gelişmelere bağlı sorunları araştırmışlardır. Bir diğer çalışmada, Türkiye'de kırmızı et tüketiminin nüfusun yapısına göre istenen düzeyde olmadığı, temel sorunun perakende fiyatların yüksek olduğu ifade edilmiştir [1]. Çoklu regresyon analizi ile sığır eti fiyatını tahmin eden değişkenleri (et TÜFE oranı, dünya sığır eti fiyatı, Türkiye kırmızı et üretim miktarı, kişi başına et tüketimi, kanatlı eti üretim miktarı, döviz kurları, GSYİH değişimi ve hayvancılık destekleri) araştırmışlardır [14].

$\mathrm{Bu}$ çalışmada, bireylerin sosyo-ekonomik ve demografik kavramlarının kırmızı et tüketim davranış ve alışkanlıkları üzerine etkilerinin araştırması amaçlanmıştır.

\section{Materyal ve Metot}

Çalışmanın populasyonunu Bingöl ve çevre illerde yaşayan kişiler oluşturmaktadır. Ancak insan populasyonunun tamamına ulaşmak ve hakkında bilgi edinmek zaman ve maliyet bakımından zor denecek kadar imkânsız örnekleme yoluna gidilmiştir. 2019 yılı Ekim ayında ağırlıklı olarak Bingöl ili ve çevre illerinde (Elazığ, Malatya, Muş, Bitlis, Tunceli, Van, Şanliurfa, Diyarbakır ve Gaziantep) illerinde 20 soruluk anket çalışması yapılmış ve rasgele olarak toplam 450 kişiye uygulanmıştır. Ancak anketlerden 123 tanesi eksik ve hatalı doldurulduğundan anketlerden 327 tanesi analize dâhil edilmiştir.

Çalışmada demografik özellikler ile kırmızı et tüketim alıșkanlıkları ve tercihleri arasındaki ilişsiyi incelemek amacıyla ele alınan değişkenler 2 kümede toplanmıştır. Birinci 
kümede cinsiyet, yaş, meslek, aylık gelir ve aylık gıda harcaması değişkenleri yer almıştır. İkinci kümede ise tüketim tercihi, tüketim miktarı, tüketim sıklığı, tüketim nedeni, kırmızı et türü, tüketim şekli ve alındığı yer değişkenleri yer almaktadır.

Doğrusal kanonik korelasyon analizinde; değişkenlerin çok değişkenli normal dağılım göstermesi, setlerdeki veri sayısının yeterince fazla olması, veri setinde aykırı değerlerin olmaması ve değişkenler arası tam korelasyon bulunmama [15] gibi varsayımlar sağlanmazsa Doğrusal Olmayan Kanonik Korelasyon Analizi kullanılır [16].

Doğrusal Olmayan Kanonik Korelasyon Analizi yöntemi optimum ölçeklendirme ile kategorik korelasyon analizine karş1lık gelir. $\mathrm{Bu}$ analizin amac1, iki veya daha fazla değişken setinin birbirine ne kadar benzediğini ifade eder. Kümeler arası ilişkilerde düşük boyutlu bir uzayda varyansı hesaba katmaktadır. Doğrusal Olmayan Kanonik Korelasyon Analizi, eşit aralıklı bir ölçüm düzeyi almaz [17].

$\mathrm{Bu}$ yöntemin en önemli özelliği, değişkenlerin ölçek düzeylerini araştırmacının seçebilmesi imkânıdır [18]. Doğrusal Olmayan Kanonik Korelasyon Analizi yöntemi sadece kategorik değişkenlere uygulanır. Eğer veri setinde sayısal değişken varsa, değişkenler kategorik hale getirilmelidir [19].

Doğrusal Olmayan Kanonik Korelasyon Analizi yönteminde orijinal veri alt setleri yerine gösterge matrisler $\left(\mathrm{G}_{\mathrm{j}}\right)$ kullanılır. A ğırlıklar yerine de $Y_{j}$ kategori sayısallaştırma matrisi kullanılır [20].

$\mathrm{K}$ tane set için genelleştirilmiş kayıp fonksiyonu

$$
\sigma_{m}(X, Y)=K^{-1} \sum_{k} S S Q\left(X-\sum_{j \in J_{k}} G_{j} Y_{j}\right)
$$

biçimindedir. Burada $\mathrm{m}$ : toplam değişken sayısı, k: set sayısı, SSQ: Vektör ya da matrislerin köşegen elemanlarının karelerinin toplamıdır. $Y_{j}$ ve $X$ değişkenlerinin de normal olması ve diklik şartının sağlanması gerekir. $\mathrm{Bu}$ varsayım $\mathrm{U}^{\prime} \mathrm{X}=0$ ve $\mathrm{X}^{\prime} \mathrm{X}=1$ ile gösterilir
[21]. K küme sayısı olmak üzere, kayıp fonksiyonu;

$$
\sigma_{j}(X, Y, T)=K^{-1} \sum_{k} S S Q\left(X-G_{j} Y_{j}\right)
$$

eşitliği ile tanımlanır[22].

Doğrusal Olmayan Kanonik Korelasyon Analizi için uyum iyiliği ölçüsü önemlidir. Özdeğerlerin toplamı, çözümün uyum iyiliğinin değerlendirilmesinde kullanılır. Uyum iyiliği, bir örneğin öngörülen bir dağılımdan gelip gelmediğini belirlemek için hesaplanan değerdir [23].

Doğrusal Olmayan Kanonik Korelasyon Analizi uygulamasında, test değeri olarak kanonik korelasyon katsayısı kullanılır ve aşağıdaki gibi hesaplanır [17, 20].

$$
\rho_{k}=\frac{\text { set sayısı } * \text { özde ğer }-1}{\text { set sayısı }-1}
$$

\section{Bulgular ve Tartışma}

Araştırmada iki veri seti kullanılmıştır. Veri setlerinden ilki Set-1 olarak adlandırılmış olup, toplam beş değişkenden oluşmuştur. $\mathrm{Bu}$ değişkenler cinsiyet, yaş, meslek, aylık gelir, aylık gıda harcaması değişkenleridir. İkinci veri seti ise Set-2 olarak adlandırılmıştır ve tüketim miktarı, tüketim sıklığ1, tüketim nedeni, kırmızı et tercihi, kırmızı et türü, alındığ 1 yer ve tercih şekli olmak üzere 7 değişkenden ibarettir. Çalışmada kullanılan iki veri setine ait frekans dağılımları Tablo 1'de verilmişsir. 
Tablo 1. Kullanılan Değişkenlere Ait Frekans Dağılımları

\begin{tabular}{|c|c|c|c|c|}
\hline & Değişkenler & Anket cevapları & Frekans & Oran $(\%)$ \\
\hline \multirow[t]{24}{*}{ Set-1 } & \multirow[t]{3}{*}{ Cinsiyet } & Erkek & 220 & 67,3 \\
\hline & & Kadın & 107 & 32,7 \\
\hline & & Toplam & 327 & 100 \\
\hline & \multirow[t]{5}{*}{ Yaş } & $<25$ & 216 & 66,1 \\
\hline & & $25-39$ & 66 & 20,2 \\
\hline & & $40-49$ & 25 & 7,6 \\
\hline & & $>50$ & 20 & 6,1 \\
\hline & & Toplam & 327 & 100 \\
\hline & \multirow[t]{6}{*}{ Mesleği } & Öğrenci & 191 & 58,4 \\
\hline & & Memur & 60 & 18,3 \\
\hline & & Serbest meslek & 54 & 16,5 \\
\hline & & İşçi & 14 & 4,3 \\
\hline & & Ev hanımı & 8 & 2,4 \\
\hline & & Toplam & 327 & 100 \\
\hline & \multirow[t]{5}{*}{ Aylık gelir } & 2000-3000 TL & 149 & 45,6 \\
\hline & & $3000-4000 \mathrm{TL}$ & 66 & 20,2 \\
\hline & & $4000-5000 \mathrm{TL}$ & 69 & 21,1 \\
\hline & & 5000 TL üstü & 43 & 13,1 \\
\hline & & Toplam & 327 & 100 \\
\hline & \multirow[t]{5}{*}{ Aylık gida harcaması } & $500-1000 \mathrm{TL}$ & 189 & 57,8 \\
\hline & & $1000-1500 \mathrm{TL}$ & 101 & 30,9 \\
\hline & & $1500-2000 \mathrm{TL}$ & 19 & 5,8 \\
\hline & & 2000 TL üzeri & 18 & 5,5 \\
\hline & & Toplam & 327 & 100 \\
\hline \multirow[t]{8}{*}{ Set 2} & \multirow[t]{3}{*}{ Tüketim tercihi } & Evet & 292 & 89,3 \\
\hline & & Hayır & 35 & 10,7 \\
\hline & & Toplam & 327 & 100 \\
\hline & \multirow[t]{5}{*}{ Aylık tüketim miktarı } & $0-1 \mathrm{~kg}$ & 196 & 59,9 \\
\hline & & $1-2 \mathrm{~kg}$ & 58 & 17,7 \\
\hline & & $2-3 \mathrm{~kg}$ & 46 & 14,1 \\
\hline & & $>3 \mathrm{~kg}$ & 27 & 8,3 \\
\hline & & Toplam & 327 & 100 \\
\hline & \multirow[t]{6}{*}{ Tüketim nedeni } & Lezzetli olması & 161 & 49,2 \\
\hline & & Sağlıklı olması & 76 & 23,2 \\
\hline & & Besleyici olması & 73 & 22,3 \\
\hline & & Kolay bulunması & 6 & 1,8 \\
\hline & & Fiyatı & 11 & 3,4 \\
\hline & & Toplam & 327 & 100 \\
\hline & \multirow[t]{4}{*}{ Tüketim sıklığı } & Haftada birkaç & 139 & 42,5 \\
\hline & & Ayda birkaç & 141 & 43,1 \\
\hline & & Yılda birkaç & 47 & 14,4 \\
\hline & & Toplam & 327 & 100 \\
\hline & \multirow[t]{4}{*}{ Kırmızı et türü } & Koyun eti & 128 & 39,1 \\
\hline & & Keçi eti & 61 & 18,7 \\
\hline & & Siğır & 120 & 36,7 \\
\hline & & Tüketmez & 18 & 5,5 \\
\hline
\end{tabular}




\begin{tabular}{cccc} 
& Toplam & 327 & 100 \\
\hline Tüketim şekli & Parça & 160 & 48,9 \\
& Kıyma & 108 & 33 \\
& İşlenmiş et & 23 & 7 \\
& Sakatat & 28 & 8,6 \\
& Tüketmez & 8 & 2,4 \\
& Toplam & 327 & 100 \\
\hline Alındığı yer & Kasap & 227 & 69,4 \\
& Market & 48 & 14,7 \\
& Hipermarket & 17 & 5,2 \\
& Süpermarket & 35 & 10,7 \\
& Toplam & 327 & 100 \\
\hline
\end{tabular}

Doğrusal olmayan kanonik korelasyon analizi ve sonuçları aşağıdaki gibi detaylı olarak anlatılmıştır.

Analizde 42 iterasyon ile yakınsama sağlanarak durağanlık elde edilmiştir. Nesne skorları ve kategori sayısallaştırmaları belirlenerek kayıp fonksiyonu minimize edilmiştir.
Analizin genel anlamlılığ verilmiştir. Kayıp ve uyum değerleri analiz sonuçlarının iyi olduğunu göstermektedir. Yani, her boyut ve değişken seti için optimal ölçekleme ile değişkenlerin ağırlıklı olarak kombine edilmesi sonucunda nesne skorlarındaki açıklanamayan varyans oranını belirtir. Analize ait genel uyum değerleri Tablo 3'te sunulmuştur.

Tablo 2. İterasyon geçmişi

\begin{tabular}{llll}
\hline & Kayıp & Uyum & Bir önceki iterasyondan fark \\
\hline 0 & 1,742069 & 0,257931 & \\
42 & 0,532391 & 1,467609 & 0,000229 \\
\hline
\end{tabular}

Tablo 3. Analizin uyum değerleri

\begin{tabular}{lllll}
\hline & \multicolumn{3}{c}{ Boyutlar } & Toplam \\
\hline \multirow{3}{*}{ Kayıp fonksiyonu } & & 1 & 2 & \\
& Set 1 & 0,247 & 0,285 & 0,532 \\
& Set 2 & 0,247 & 0,285 & 0,532 \\
& Ortalama & 0,247 & 0,285 & 0,532 \\
Özdeğer & & 0,753 & 0,715 & \\
Uyum & & & & 1,468 \\
\hline
\end{tabular}

Tablo 3'de kayip fonksiyonu ve uyum değerleri görülmektedir. $\mathrm{Bu}$ değerlere göre, ortalama kayıp değeri 1.boyut için 0,247 ve 2.boyut için 0,285'dir. Bu değerlerin, ayrı ayrı "1" değerinden çıkarılması ile özdeğerler hesaplanır. 1.boyut ve 2.boyut için özdeğerler sirasiyla 0,753 ve 0,715 olarak elde edilir. Özdeğer, her bir diskriminant fonksiyonun göreli etkinliği hakkında bilgi vermektedir.

Doğrusal olmayan kanonik korelasyon analizinde uyum, en fazla kullanılan set sayıs1 kadardır ve burada iki set olduğu için en yüksek uyum olabilirliği 2'dir. Tablo 3'e göre, modelin toplam uyumu 1,468 olarak elde edilmiș olup, \%73,4 gibi $(1,468 / 2)$ yüksek bir değere sahiptir. Ayrıca, Set-1 gerçek uyum değeri olan 1,468'nin \%51,3'ünü $(0,753 / 1,468)$ açıklayabiliyorken; Set-2 gerçek uyumun \%48,7’lik kısmını $\quad(0,715 / 1,468)$ açıklayabilmektedir.

Kanonik korelasyon katsayıları 1. Boyutta $\rho_{1}=2 * 0,753-1=0,506$ ve 2 . Boyutta $\rho_{2}=2 * 0,715-1=0,430 \quad$ olarak hesaplanmıştır. Kısaca, birinci boyuta göre 
sosyo ekonomik ve demografik değişkenler ile seçilmiş kırmızı et tüketimi değişkenleri arasında pozitif yönde \%50,6 düzeyinde bir ilişki bulunurken; ikinci boyutta bu ilişki pozitif yönde $\% 43$ düzeyindedir. Tablo 4 'de değişkenlere ait ağırlık değerleri ve bileşen yükleri gösterilmiştir.

Tablo 4. Ağırlık yükleri ve bileşen yüklemeleri

\begin{tabular}{llcccc}
\hline Set & Değişkenler & \multicolumn{2}{c}{ Boyut } & \multicolumn{2}{c}{ Boyut } \\
\hline \multirow{3}{*}{ Set-1 } & Cinsiyet & 1 & 2 & 1 & 2 \\
& Yaş & $-0,005$ & 0,198 & $-0,260$ & 0,178 \\
& Meslek & 0,677 & $-0,005$ & 0,648 & 0,145 \\
& Aylık gelir & $-0,217$ & 0,128 & 0,064 & 0,030 \\
& Aylık gida harcama & $-0,227$ & 0,849 & 0,098 & 0,808 \\
\multirow{3}{*}{ Set-2 } & Tüketim miktarı & 0,555 & $-0,058$ & 0,628 & 0,168 \\
& Tüketim sıklığ1 & $-0,067$ & $-0,323$ & $-0,171$ & $-0,469$ \\
& Tüketim nedeni & 0,393 & $-0,07$ & 0,314 & $-0,207$ \\
& Tüketim tercihi & $-0,042$ & $-0,273$ & $-0,141$ & $-0,288$ \\
& Kırmızı et türü & 0,019 & 0,313 & $-0,070$ & 0,157 \\
& Alındığ1 yer & $-0,225$ & 0,619 & $-0,397$ & 0,581 \\
& Tüketim şekli & $-0,064$ & $-0,069$ & $-0,226$ & $-0,057$ \\
\hline
\end{tabular}

Tablo 4'de görüldüğü gibi, kanonik değişkenlerin elde edilmesinde, değişkenlerin her bir boyuttaki uyuma olan katkılarını gösteren ağırlık değerleri ve bileșen yükleri mevcuttur. Bu değerler, veri setleri için hangi değişkenlerin daha yüksek etki gücüne sahip olduğu hakkında bilgi vermektedir. Tablo 4 incelendiğinde, 1 . boyutun uyum değeri için en yüksek katkıyı Set-2'de bulunan "tüketim miktarı" $(0,689)$ değişkeni sağlarken; bunu Set-1'deki "yaş" $(0,677)$ değişkeni izlemektedir. 2. boyutun uyum değeri için en büyük katkıyı Set-1'deki "aylık gelir" $(0,849)$ değişkeni sağlamıştır ve bunu Set-2'de bulunan "alındığı yer" $(0,619)$ değişkeni takip etmektedir. Bileşen yüklerinin grafiksel gösterimi Şekil 1'de sunulmuştur. 


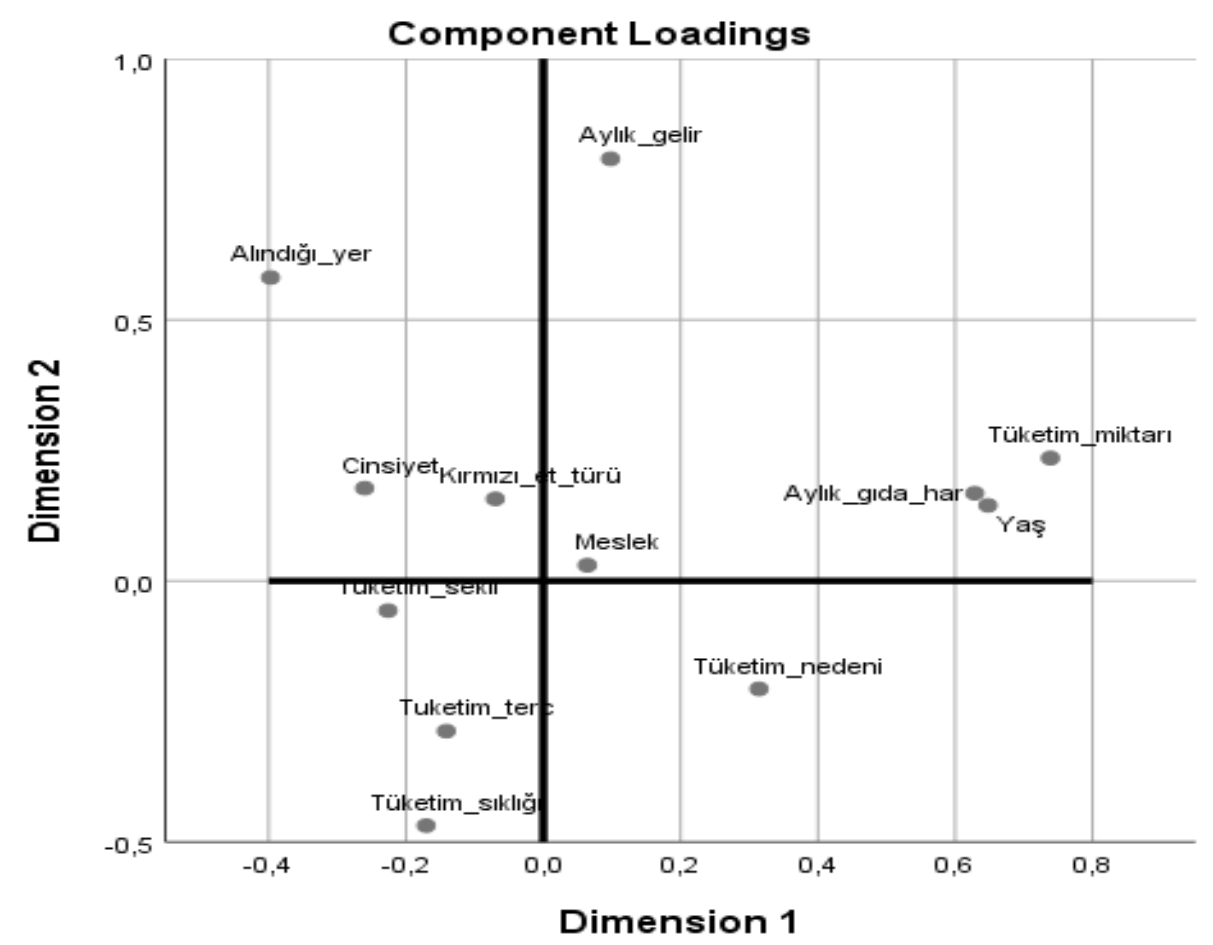

Şekil 1. Bileşen yüklerinin grafiği

Şekil 1'de gösterilen bileşen yükleri grafiğinde ele alınan değişkenlerin orijinden mümkün olduğu kadar uzak olmaları beklenir. Uzaklık derecesi daha fazla olan değişkenlerin önemi artmaktadır. Aylık gelir, alındığ 1 yer, tüketim miktarı ve tüketim sıklığı en önemli değişkenlerdir. Bunun yanında, kırmızı etin alındığı yer, cinsiyet ve kırmızı et türü ile tüketim nedeni arasında ters yönlü bir ilişki vardır. Tüketim sıklığı, tüketim tercihi ve tüketim şekli ile tüketim miktarı, aylık gıda harcaması, yaş ve meslek değişkenleri arasında ters yönlü ilişki bulunmaktadır.

Sayısallaştırma işleminin doğru olup olmadığını ve değişkenlerin ayrımsama güçlerini gösteren tekli ve çoklu uyum değerleri Tablo 5'de sunulmuştur.

Tablo 5. Tekli ve çoklu uyum gösterimi

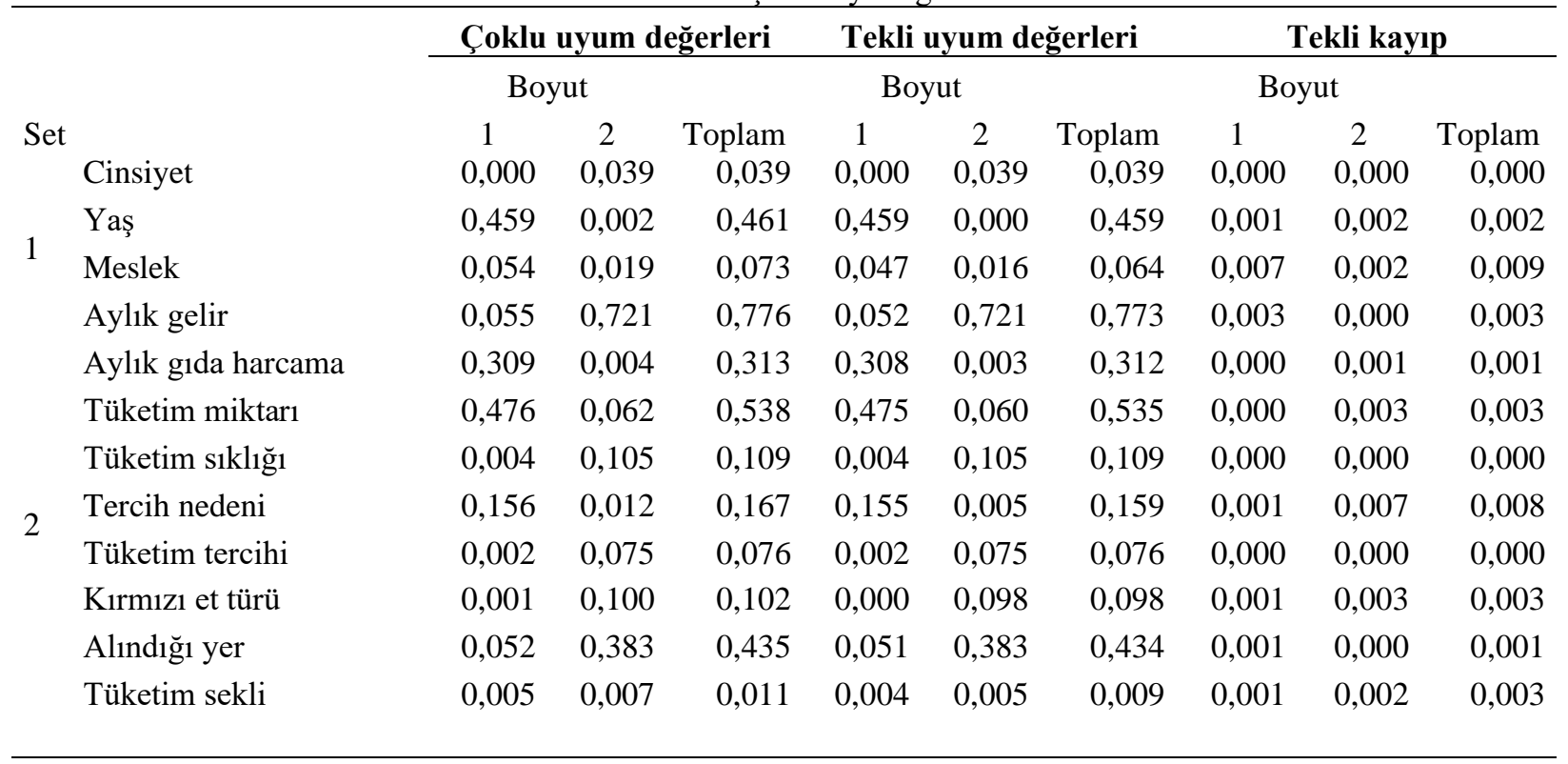


Tablo 5 değerlendirildiğinde tekli ve çoklu kayıp sütunlarının, toplam sütunundaki değerlere göre ölçek düzeylerinde bir değişiklik yapılıp yapılmayacağına göre karar verilir. $\mathrm{Bu}$ çalışmada tekli ve çoklu uyum değerleri arasında fark yok denecek kadar çok azdır. Analiz için önemli olan değişkenler çoklu uyum sütunun topla kismından görülebilir. Hangi değişkenlerin en iyi şekilde ayırt edildiğini görmek için çoklu uyum tablosu incelenir. Bu çalışmada birinci sette aylık gelir ve yaş değişkenlerinin iki boyuttaki toplam uyum değerleri sirasiyla 0,776 ve 0,461'dir. İkinci setteki tüketim miktarı ve alındığ 1 yer değişkenleri için her iki boyutta toplam uyum değerleri sirasiyla 0,538 ve 0,435 'dir. Bu sonuçlar aylık gelir, yaş, tüketim miktarı ve alındığı yer değişkenlerinin diğer değişkenlere göre daha fazla ayrımcı güç sağladığını gösterir. Çünkü diğer değişkenlerin toplam uyum değerleri daha düşüktür.

A ğırlık merkezi (centroids) sonuçları Şekil 2'de verilmiştir. Dikkat çeken sonuçlar aşağıdaki gibidir.

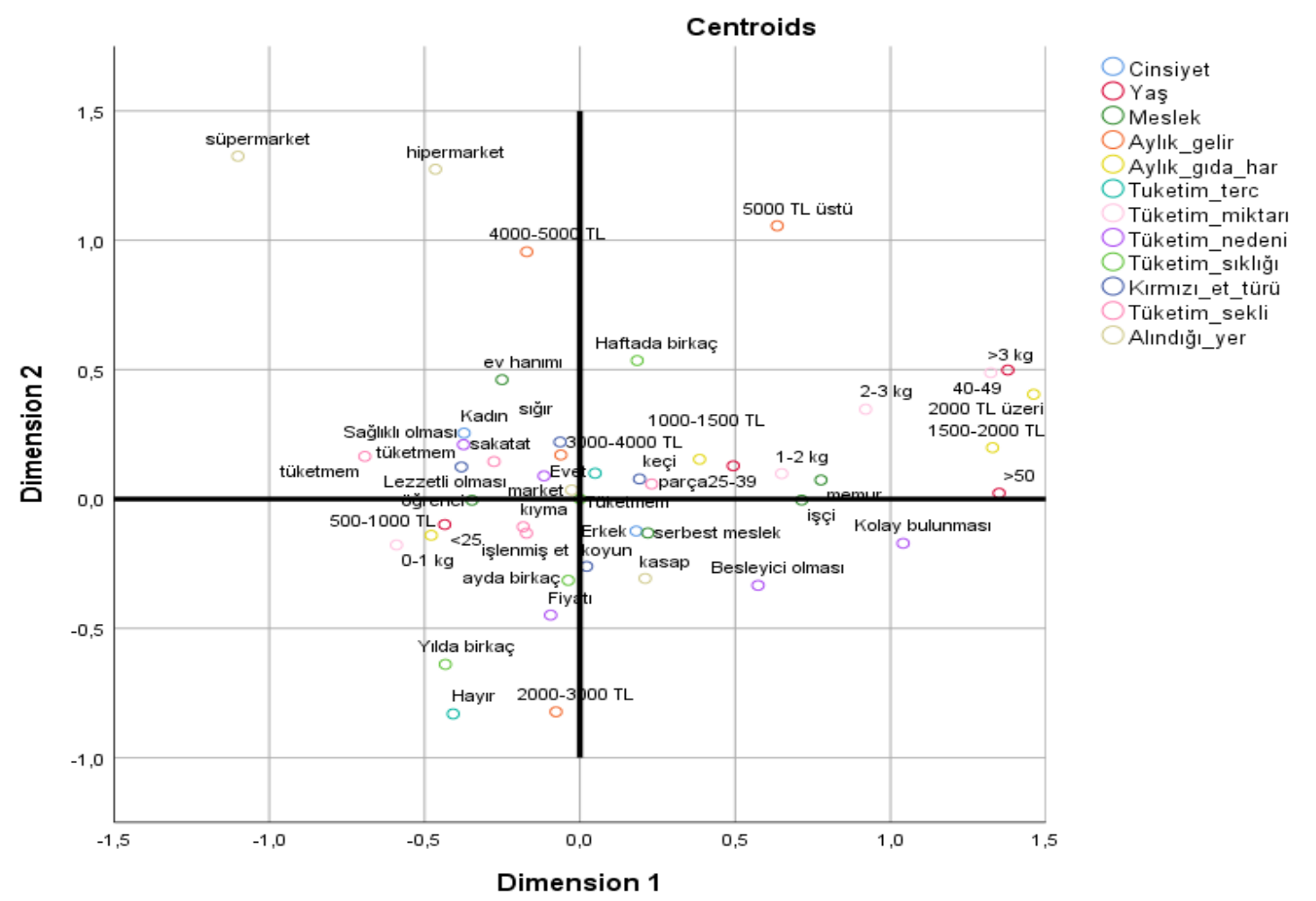

- Aylik geliri 3000-4000 lira olan kadınlar, sağlıklı ve lezzetli olması nedeniyle marketten alarak sığır etini sakatat şeklinde tüketmektedirler. Aynı şartlarda tüketmeyen kesim de bulunmaktadır.

- Aylik gida harcaması 1000-1500 lira olan 25-39 yaşındakiler parça şeklinde keçi eti aylık 1-2 kg tüketmektedir. Bu kişiler genelde memur olarak çalışanlardır. Ayrıca 50 yaş üstü aylık gida harcamas1 1500-2000 lira arasi ve 2000 liranın üzerinde olanlar $3 \mathrm{~kg}$ 'dan daha fazla et tüketmektedirler.

- İşçi ve serbest meslek sahibi erkekler besleyici olmas1 ve kolay bulunmas1 sebebiyle kasaptan koyun etini almaktadırlar.

- Aylık gida harcaması 500-1000 lira arası olan 25 yaşından küçük öğrenciler kıyma ve işlenmiş eti, fiyatı nedeniyle ayda birkaç defa $0-1 \mathrm{~kg}$ almaktadırlar.

Şekil 2. Ağırlık merkezleri (centroids) grafiği

Değişkenlere ait çoklu kategori koordinatları gösteren grafik de verilmiştir (Şekil 3). 


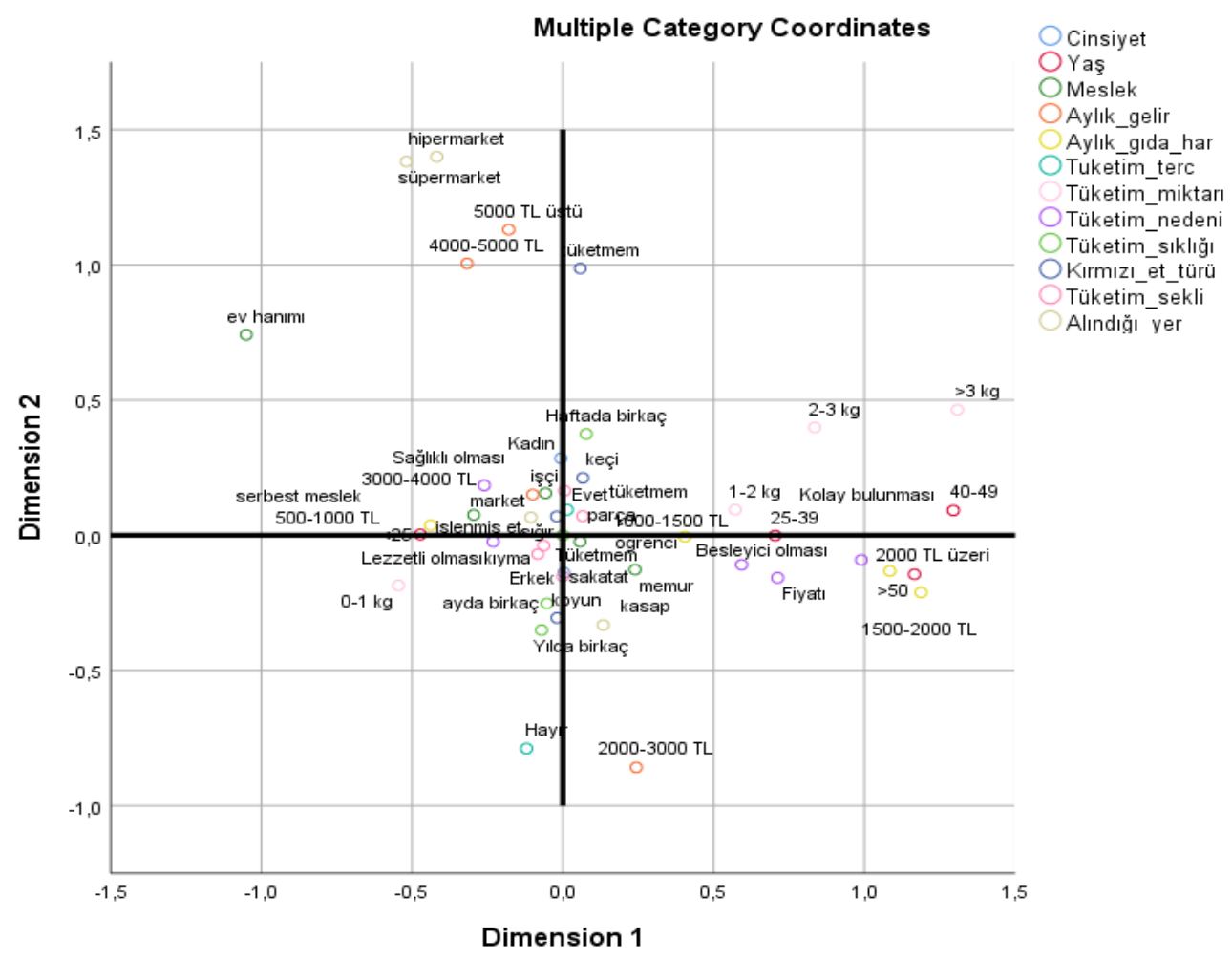

Şekil 3. Çoklu kategorilerin koordinatları

- 25-39 ve 40-49 yaş arası kişiler; haftada birkaç defa aylık gıda harcamas1 1000-1500 lira olan, kolay bulunduğu için 1-2 $\mathrm{kg}$ et tüketmeyi tercih ederler.

- 50 yaş üstü aylık gida harcaması 2000 lira üstü ve aylık geliri 2000-3000 lira arası olan memurlar, besleyici ve fiyatı sebebiyle kasaptan et alarak sakatat şeklinde tüketirken, öğrenciler kırmızı et tüketmemektedir.

- Erkekler ayda veya yılda birkaç defa lezzetli olan koyun etini kryma şeklinde almaktadırlar.

- Aylik geliri 3000-4000 lira ve gida harcaması 500-1000 lira olan işçiler, serbest meslek sahibi olanlar ve kadınlar sığır etini işlenmiş olarak marketten almaktadır. Aylık geliri 4000-5000 lira ve 5000 lira üstü olanlar süpermarket ve hipermarketten et almaktadır.

Hane başına ortalama aylık tüketimi bir çalışmada aylık 7,16 kg olarak tespit edilmiştir. Et türü olarak dana, sığır, koyun, keçi, kuzu, manda ve diğer et türleri tüketilmiş en fazla tüketim sırasıyla koyun, kuzu ve sığır etleridir. Kırmızı et kıyma, kuşbaşı, biftek ve pirzola olarak tüketilmiş olup, kıyma şeklide tüketim diğer tüketim şeklinden daha fazla olmuştur [24]. $\mathrm{Bu}$ çalışmada elde edilen sonuçlarla farklılık göstermektedir.

Şeker ve ark.[10]'un Elazığ ilinde yürüttüğü bir anket araştırmasında, kişilerin \%58,4'ünün öncelikli olarak kırmızı eti tercih ettiği ve en çok tercih edilen kırmızı et türünün de sırasıyla "sı̆̆ır" (\%55,3), "koyun" (\%15,3), "keçi" $(\% 11,7)$ olduğu saptanmıştır. Katılımcıların \%66,6'sının kırmızı eti kasaptan aldıkları bildirilmiştir. $\mathrm{Bu}$ araştırma bulguları ile tercih edilen et türü bakımından farklılık gösterse de etin alındığ 1 yer bakımından uyum içindedir.

Diğer bir çalışmada, ailelerin ortalama \% 63,4'ü belli bir kasaptan, \%21,1'i ise kasaplar çarşısından satın aldıklarını belirtmişlerdir. Gelir grupları ile etin satın alındığ 1 yer arasında istatistik olarak çok önemli bir ilişki saptanmıştır. Tercih edilen kırmızı et türü olarak tüm gelir gruplarında sığır etinin ilk sırada yer aldığ bulgularıyla farkl1l1k göstermektedir [25]. [12]'in çalışmasında Siirt ilinde tüketicilerin ilk sırada tercih ettikleri et çeşitleri sırasıyla koyun $(\% 56,3)$, keçi $(\% 21,9)$ ve dana $(\% 20,6)$ 'dır. Bu çalışmada olduğu gibi en fazla tercih edilen et koyun eti olmuştur. Aynı 
çalışmada ankete katılan bireylerin aylık et tüketim miktarı durumu ise $2 \mathrm{~kg}$ 'dan az et tüketenler \%23,6, 2-5 kg arasında et tüketenler $\% 49,1,5-10 \mathrm{~kg}$ et tüketenler $\% 19,3$ ve 10 $\mathrm{kg}$ 'dan fazla et tüketenler ise $\% 8,1$ oranında olmuştur. $\mathrm{Bu}$ çalışmada ise daha farklı sonuçlara ulaşılmıştır.

Doğrusal Olmayan Kanonik Korelasyon Analizi yöntemi ile ilgili çalışmalarda, modelin toplam uyumunu [20] 1,651, [26] 1,423, [27] $1,610, \quad[28] 1,430, \quad$ [29] 1,592 olarak bulmuşlardır ve bu çalışmada elde edilen değere (1.468) yakındır. Ortalama kayıp değeri [19], [26], [28] ve [29] tarafindan sirasiyla $0,209, \quad 0,577, \quad 0,570$ ve 0,408 olarak bulunmuştur. $\mathrm{Bu}$ çalışmada hesaplanan ortalama kayıp değeri Filiz ve Kolukısaoğlu [19]'un bulduğu değerle farklilık gösterirken diğer çalışmalarda elde edilen sonuçlarla benzerlik göstermiştir.

\section{Sonuç}

$\mathrm{Bu}$ çalışmada, Doğrusal Olmayan Kanonik Korelasyon Analizi yöntemi ile iki veri seti arasındaki ilişkiler incelenmiştir. Bunun için, 2019 y1lında Bingöl ili ve çevre illerde uygulanan ankette kişilerin sosyo-ekonomik ve demografik özellikleri ile kırmızı et tüketim alışkanlıklarını içeren veriler kullanılmıştır. Çalışma sonucunda, seçilmiş sosyo-ekonomik ve demografik özellikler ile et tüketim alışkanlıkları arasındaki ilişkinin, kanonik korelasyon katsayısına göre birinci boyutta $\% 50,6$ ve ikinci boyutta \%43 olduğu saptanmıştır.

Analiz sonucunda kırmızı etin alındığ 1 yer, cinsiyet ve kırmızı et türü ile tüketim nedeni arasında ters yönlü kuvvetli bir ilişki olduğu bileşen yükleri grafiğine bakılarak görülmüştür. Benzer şekilde tüketim sıklığ 1 , tüketim tercihi ve tüketim şekli ile tüketim miktarı, aylık gıda harcaması, yaş ve meslek değişkenleri arasında da ters yönlü ilişki bulunmaktadır.

Aylık geliri 3000-4000 lira olan kadınlar, sağlıklı ve lezzetli olması nedeniyle marketten sığır etini alarak sakatat şeklinde tükettikleri; 50 yaş üstünde aylık gıda harcaması daha fazla olanların $3 \mathrm{~kg}$ 'dan fazla et tükettikleri, işçi ve serbest meslek sahiplerinin kolay bulduklarından kasaptan et aldıkları centroids grafiğine bakılarak görülmüştür. Literatür taramas1 sonucunda son zamanlarda yapilan diğer bazı çalışmalarda olduğu gibi, bu çalışmada kırmızı eti aylık geliri 2000-3000 lira arasında olanların daha fazla tercih ettikleri ve hane halkının yarıdan fazlasının aylık gıda harcamasının 1000 lira altında olduğu saptanmıştır. Koyun eti ve sığır eti tüketenler diğer kırmızı et tüketenlerden daha fazladır. 25 yaş altı genç kesimin diğer yaş gruplarından daha fazla kırmızı et tükettiği dikkat çekmektedir.

Yapılan bu çalışma sonucunda Doğrusal Olmayan Kanonik Korelasyon Analizi yöntemi uygulama sonuçlarının grafikler üzerinden yorum yapıldığ 1 net bir şekilde görülmüştür. Buna ilave olarak kanonik korelasyon katsayis1 hesaplanmış ve test edilmiştir. Doğrusal olmayan kanonik korelasyon analizi sonucunda kayıp fonksiyonu 42 iterasyonda en küçüklenmiştir. İlk boyut için değişkenlerin ağırlıklı kombinasyonu tarafindan açıklanamayan varyans oran1 0,247 , ikinci boyut için ise 0,285 olarak bulunmuştur. Uyum değeri yani toplam açıklanan varyans 1,468 olarak hesaplanmıştır. Bu değerin alabileceği en büyük değer 2 olduğundan bulunan uyum değerinin iyi olduğu söylenebilir. Boyutlardaki gerçek uyum değerleri de sirasıyla 0,513 ve 0,487 olarak bulunmuştur. İlerleyen çalışmalarda grafikleri destekleyici diğer yöntemler de eklenerek yorumlanması daha iyi sonuçları ortaya koyacaktır.

\section{Teşekkür}

Anket Bingöl Üniversitesi Ziraat Fakültesi Bitki Koruma ve Tarla Bitkileri bölümünde öğrenim gören bazı öğrenciler tarafından yürütülmüştür. Anketin uygulanmasında görev yapan Alperen Furkan, Ekrem Öz, Fevzi Polat, Harun Kurt, Mehmet Emin Aydın, Hac1 Mustafa Necati Kişif ve Engin Artunç isimli öğrencilere çok teşekkür ederim.

\section{Çıkar Çatışması Beyanı}

Makale yazarı, herhangi bir çıkar çatışması olmadığını beyan eder.

\section{Araştırmacının Katkı Oranı Beyan Özeti}

Yazar, makaleye \%100 oranında katk1 sağlamış olduğunu beyan eder. 


\section{Kaynakça}

[1] Saygın Ö., Demirbaş N. Türkiye'de kırmızı et tüketimi: sorunlar ve öneriler, Selçuk Tarım ve Gida Bilimleri Dergisi 2018; 32(3): 567574.

[2] Yılmaz İ. Türkiye'de Kırmızı Et Sektörü, Sorunları ve Çözüm Önerileri Paneli, Namık Kemal Üniversitesi, 02.03.2011, Tekirdağ.

[3] Arıtaşı C. Et ve Balık İşleme Teknolojisi Ders Notları. Namık Kemal Üniversitesi 2009; Tekirdağ.

[4] Yücel A. Et ve su ürünleri teknolojisi. IV. Bask1. Uludağ Üniversitesi Ziraat Fakültesi Ders Notlar1 2001; No: 47, Bursa.

[5] OECD, Ekonomik Kalınma ve İşbirliği Örgütü. 2018. Ülkelerin et tüketim rakamları açıklandı! Bakın Türkiye'de kişi başına ne kadar et düşüyor. https://www.hurriyet.com.tr/galeri-ulkelerin-ettuketim-rakamlari-aciklandi-bakin-turkiyede-kisibasina-ne-kadar-et-dusuyor-41331165/7. Erişim Tarihi:12.08.2020.

[6] FAO. Dünya Gıda ve Tarım Örgütü. FAOSTAT, Livestock Primary. http://www.fao.org/faostat/en/\#data/QL (Erişim 27.12.2020).

[7] İlhan GM. Tekirdağ ilinde kırmızı et tüketim alışkanlıklarının analizi, Namık Kemal Üniversitesi Fen Bilimleri Enstitüsü, Tekirdağ, Yüksek Lisans Tezi 2011.

[8] Stefanikova Z., Sevcikova L., Jurkovicova J., Sobotova L., Aghova L. Positive and negative trends in university students' food intake, Bratisl Lek Listy 2006; 107: 217-220.

[9] Karakuş K., Aygün T., Alarslan E. Gaziantep ili merkez ilçede kırmızı et tüketim alışkanlıkları, Yüzüncü Yıl Üniversitesi Tarım Bilimleri Dergisi 2008; 18(2): 113-120.

[10] Şeker İ., Özen A., Güler H., Şeker P., Özden İ. Elazığ'da kırmızı et tüketim alışkanlıkları ve tüketicilerin hayvan refahı konusundaki görüşleri, Kafkas Üniversitesi. Veteriner Fakültesi Dergisi 2011; 17(4): 543550.
[11] Akçay Y., Vatansever Ö. Kırmızı et tüketimi üzerine bir araştırma: Kocaeli ili kentsel alan örneği, Journal of Institute of Social Sciences 2013; 4(1): 43-60.

[12] Kibar M., Mikail N., Yılmaz A. Siirt İli merkez ilçede kırmızı et tüketim alışkanlıkları ve tüketimi etkileyen faktörler, Türk Tarım ve Doğa Bilimleri Dergisi 2019; 6(4): 720-728.

[13] Saygın Ö., Demirbaş N. Türkiye'de kırmızı et sektörünün mevcut durumu ve çözüm önerileri, Hayvansal Üretim 2017; 58(1): 74-80.

[14] Tengiz AZ., Tengiz ZM. Türkiye'de sığır eti birim fiyat çalışması, International Conference on Eurasian Economies 18-20 June 2018 Tashkent, Uzbekistan.

[15] Özdamar K. Paket Programlar ile İstatistiksel Veri Analizi-2. Yenilenmiş 5. Bask1. Kaan Kitabevi 2004.

[16] Süt N. Doğrusal olmayan kanonik korelasyon analizi ve bir uygulama, Trakya Üniversitesi Sağlık Bilimleri Enstitüsü, Yüksek Lisans Tezi 2001.

[17] Gürsakal S. Sosyal bilimlerde SPSS uygulamalı çok değişkenli istatistiksel analiz teknikleri, Dora Basım-Yayın Dağıtım Ltd. Şti. 2019; Bursa.

[18] Aydın S., Görmüş AȘ., Altıntop MY. Öğrencilerin memnuniyet düzeyleri ile demografik özellikleri arasındaki ilişkinin doğrusal olmayan kanonik korelasyon analizi ile incelenmesi: Meslek Yüksekokulu'nda bir uygulama, AİBÜ Sosyal Bilimler Enstitüsü Dergisi 2014; 14(1): 35-58.

[19] Filiz Z., Kolukısaoğlu S. Doğrusal olmayan kanonik korelasyon analizi ve bir uygulama, Uluslararası Yönetim İktisat ve İşletme Dergisi 2012; 8(16): 59-75.

[20] Özer OO., Özden A. Ege Bölgesi yaş meyve ve sebze ihracatçılarının bireysel farklılıklarının incelenmesi, Tarım Ekonomisi Dergisi 2013; 19(1): 71-79.

[21] Gifi A. Nonlinear Multivariate Analysis, John Wiley and Sons, New York 1990. 
[22] Tuna GT. Parametrik olmayan çok değişkenli analiz tekniği homojenleştirme analizi, Yayınlanmamış Doktora Tezi, Mimar Sinan Üniversitesi 2004, İstanbul.

[23] Giray S. Doğrusal olmayan kanonik korelasyon analizi ve yaşam memnuniyeti üzerine bir uygulama, Marmara Üniversitesi Sosyal Bilimler Enstitüsü, Yayınlanmış Doktora Tezi, 2011.

[24] Çivi H., Gürler Z., Esengün K., Karkacıer O. Tokat il merkezinde yaşayan hanehalklarının kırmızı et tüketim durumu üzerine bir araştırma, Gaziosmanpaşa Üniversitesi Ziraat Fakültesi Dergisi 1993; 10: 108-115.

[25] Atay O., Gökdal Ö., Aygün T., Ülker H. Aydın İli Çine İlçesinde kırmızı et tüketim alışkanlıkları, 4. Ulusal Zootekni Bilim Kongresi, 1-3 Eylül 2004, Süleyman Demirel Üniversitesi, Ziraat Fakültesi Zootekni Bölümü.

[26] Bülbül Ş., Giray S. İş ve özel yaşam (iş dış1 yaşam) memnuniyeti arasındaki ilişki yapısının doğrusal olmayan kanonik korelasyon analizi ile incelenmesi, Anadolu Üniversitesi Sosyal Bilimler Dergisi 2012; 12(4): 101-114.

[27] Filiz Z., Kolukısaoğlu S. Doğrusal olmayan kanonik korelasyon analizi ve lokanta müşterilerinin memnuniyeti üzerinde bir uygulama, EKEV Akademi Dergisi 2012; 16(51): 357-368.

[28] Filiz Z., Kolukısaoğlu S. Doğrusal olmayan kanonik korelasyon analizinin depresyon, anksiyete ve stres ölçeğine uygulanmas1, Yönetim Bilimleri Dergisi 2015; 13(26): 241-259.

[29] Özkan M. Doğrusal olmayan kanonik korelasyon analizi ile seçilmiş demografik ve sosyo-kültürel kavramların değerlendirilmesi, Eskişehir Osmangazi Üniversitesi İIBF Dergisi 2019; 14(2): 391-408. 